\title{
ANALYSIS INFORMATION SYSTEM OF INPATIENT BILLING SYSTEM'S SUPPORT FOR CONSUMABLES LOGISTICS USING PIECES FRAMEWORK: CASE STUDY PROMEDIKA HOSPITAL
}

\author{
Hoga Saragih ${ }^{1}$, Lina Lo ${ }^{2}$, Bobby Reza and Didik Setiyadi ${ }^{3}$ \\ ${ }^{1}$ Fakultas Teknik dan Ilmu Komputer - Universitas Bakrie \\ Kampus Kuningan, Kawasan Epicentrum, Jl. H.R. Rasuna Said Kav. C-22, 12920, Indonesia \\ ${ }^{2}$ Program Studi Sistem Informasi, STMIK Widya Dharma, \\ Jalan H.S. Cokroaminoto Gang Palem Pontianak, 78116, Indonesia \\ ${ }^{3}$ Program Pasca Sarjana, STMIK Eresha, Jl. Haji Samali No. 51, Kalibata, 12740, Indonesia \\ E-mail: hogasaragih@gmail.com
}

\begin{abstract}
Billing system plays an important role in hospital since it ensure financial stability of the hospital. Complexity of hospital generate a complex billing system as well, thus further learning and study about billing system related to other basic functions in hospital is needed. New billing system released by Ministy of Health of Republic Indonesia which is Diagnosis based pushes hospitals to fix its billing system and functions related such as medical and non medical material management. Clasical reason "for patient safety and care" will become a deadly reason for hospital because of high nursing cost. Hospital can't anymore charge a huge bill of consumables to patient when Diagnosis Related Group Billing is required to used by hospitals.
\end{abstract}

Keywords: billing system, hospital billing, hospital logistics, consumables logistics, hospital

Abstrak

\begin{abstract}
Sistem penagihan memegang peranan penting dalam rumah sakit karena menentukan ketahanan keuangan rumah sakit. Kompleksitas rumah sakit menimbulkan sistem penagihan yang juga kompleks sehingga diperlukan pembelajaran dan kajian mendalam mengenai sistem penagihan terkait dengan fungsi-fungsi dasar dalam rumah sakit. Perkembangan sistem penagihan baru yang dirintis Kementerian Kesehatan Republik Indonesia yang berbasis Diagnosis memberi tekanan bagi rumah sakit untuk membenahi sistem penagihannya dan fungsi-fungsi terkait, di antaranya manajemen barang medis dan non medis dalam rumah sakit. Alasan klasik "demi kepentingan pengobatan pasien" akan menjadi bumerang bagi rumah sakit karena pembengkakan biaya perawatan. Rumah sakit tidak dapat lagi memberikan tagihan besar untuk bahan habis pakai bagi pasien ketika penagihan berbasis diagnosis wajib digunakan oleh rumah sakit.
\end{abstract}

Kata kunci: sistem billing, billing rumah sakit, tagihan rumah sakit, logistik, bahan habis pakai

\section{Pendahuluan}

Perubahan struktural dan peningkatan pasar yang dinamis dalam sektor pelayanan kesehatan telah memicu kebutuhan Rumah Sakit akan penekanan biaya dan optimalisasi proses operasional. Adopsi teknologi Informasi dan komunikasi (ICT) yang baru dilihat sebagai suatu opsi dan kesempatan untuk meningkatkan efisiensi dan efektivitas, bahkan sebagai kesempatan untuk meningkatkan kualitas pelayanan kesehatan [6].

Pertukaran informasi yang semakin intens antar bagian dan peningkatan transaksi akan mendorong peningkatan kebutuhan tenaga kerja dan biaya operasional. Hal ini tentunya akan berdampak pada biaya pelayanan dan farmasi yang meningkat. Karena biaya farmasi yang terus meningkat, farmasi Rumah Sakit secara khusus akan membutuhkan peningkatan keahlian dan teknologi untuk meningkatkan proses pemesanan dan persediaan. E-procurement merupakan salah satu solusi yang ditawarkan teknologi IT. Namun karena alasan-alasan profesionalisme dan batasan dalam dunia kesehatan, e-procurement sulit diimplementasikan.

Dalam bidang usaha lain, biaya procurement dapat ditekan dengan kebijakan-kebijakan perusahaan dan kontrak-kontrak pembelian yang efisien. Namun dalam bidang rumah sakit, 
kebijakan dan kontrak sangat sulit dilakukan karena yang diutamakan adalah perawatan dan pengobatan bagi pasien. Jenis produk yang beragam dengan berbagai keunggulannya masingmasing membuat pada dokter memiliki preferensi masing-masing yang kemudian mempengaruhi harga beli untuk satu jenis produk, misalnya sarung tangan steril; ada berbagai merek dengan keunggulan masing-masing dan pengguna (medis dan para medis) memiliki preferensi yang mengakibatkan sulitnya kontrak pembelian yang efisien dilakukan. Ketika muncul produk sejenis dengan keunggulan yang lebih banyak, pengguna akan segera beralih walaupun persediaan dalam gudang masih ada.

Kesulitan dan tantangan seperti ini mendorong manajer logistik dan pembelian untuk lebih jeli dan piawai dalam negosiasi dengan para distributor. Walaupun kadang kala perjanjian dengan pihak prinsipal (pabrik pembuat) juga sangat mempengaruhi harga beli. Dalam laporannya, Dooley merekomendasikan untuk memulai dengan perencanaan logistik sebelum membuat keputusan jangka pendek (misalnya mengganti distributor atau membuat perjanjian dengan prinsipal) [1].

Sebuah sistem penagihan (billing) merupakan pondasi yang kuat bagi kelangsungan Rumah Sakit secara keuangan. Memilih dan mengimplementasikan sistem billing memerlukan pertimbangan manajerial yang tidak mudah; termasuk pertimbangan lingkungan, teknis dan perencanaan. Struktur organisasi dan kedinamisan organisasi adalah yang terpenting.

Kebanyakan Rumah Sakit membuat batas yang jelas antara segmen organisasi yang berhubungan dengan manajemen keuangan dan segmen yang berhubungan dengan operasional administrasi sehari-hari. Ini jadi agak menyulitkan karena informasi untuk penagihan pasien juga digunakan untuk registrasi rekam medis dan pelayanan sehari-hari (termasuk pelayanan farmasi) [10].

Kompleksitas industri rumah sakit menghasilkan proses yang juga kompleks untuk sistem penagihan pelayanan kesehatan. Pemahaman proses ini membutuhkan berbagai pelatihan dan edukasi yang terus menerus [7].

Pada sistem billing rawat inap (inpatient), ada beberapa jenis biaya yang tergabung menjadi biaya rumah sakit; biaya fasilitas, biaya tambahan dan biaya dokter. Biaya fasilitas terdiri dari biaya kamar, biaya perawatan, jasa tindakan medis, dan penggunaan berbagai alat kesehatan. Biaya ini merupakan biaya harian yang dikenakan pada pasien untuk menempati tempat tidur di rumah sakit; semakin intensif perawatan yang diperlukan, semakin tinggi biaya yang diperlukan.
Biaya tambahan adalah biaya-biaya yang tidak tercakup dalam biaya fasilitas, antara lain biaya radiologi, biaya laboratorium dan biaya farmasi. Biaya dokter adalah jasa yang diberikan kepada dokter dan asistennya untuk pelayanan yang diberikan. Proses penagihan diuraikan dalam Gambar 1 [7].

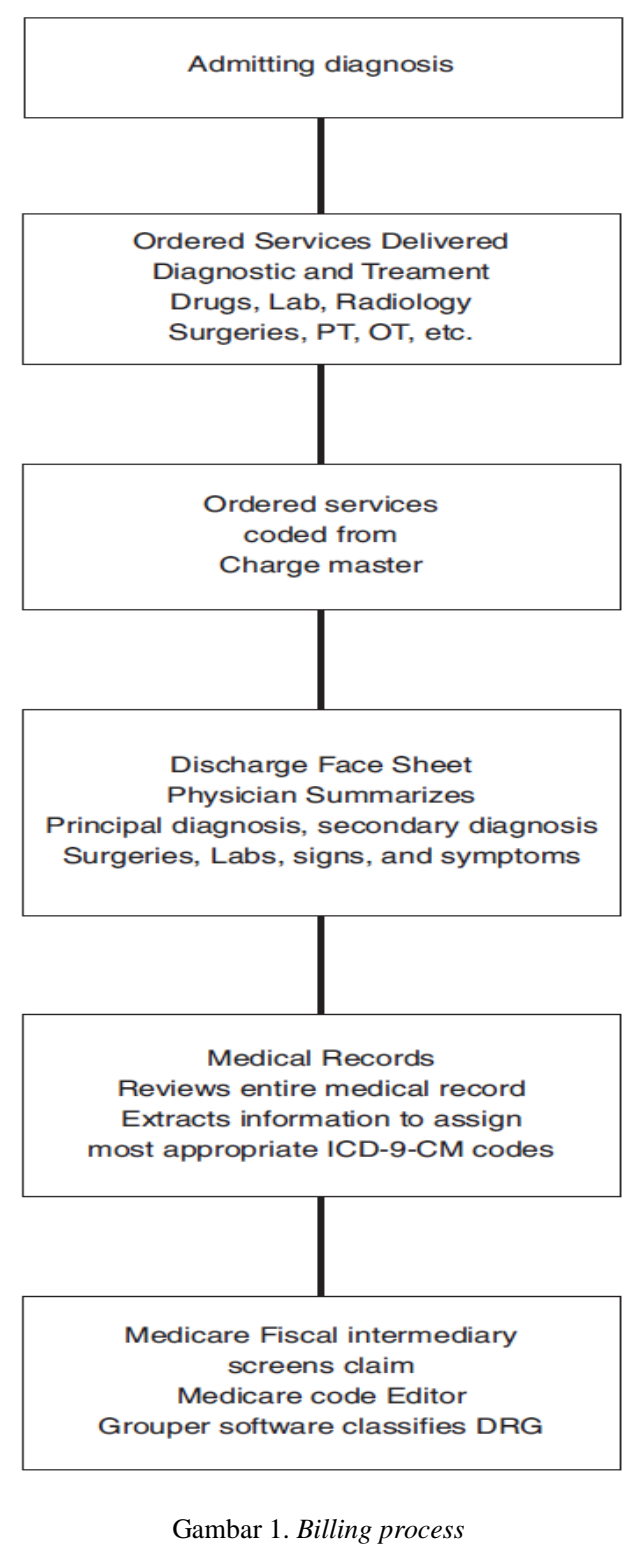

Pembayaran terhadap pelayanan kesehatan yang paling banyak dipakai di Indonesia saat ini adalah sistem fee for service. Pola pembayaran ini memiliki kecenderungan pembengkakan volume pelayanan sehingga mengakibatkan kesulitan penyusunan anggaran dan manajemen logistik [3].

Peranan staf medis dan perawat dalam proses pengadaan barang di Rumah Sakit sangat penting. Bahkan, staf pengadaan, staf medis dan perawat yang bertanggung jawab untuk a) 
mendefinisikan kebutuhan rumah sakit, b) menetapkan persyaratan fisik atau karakteristik (spesifikasi teknis) barang dan peralatan yang akan dibeli, c) penjadwalan pengadaan d) melakukan riset pasar dan e) menetapkan prosedur, syarat dan kondisi untuk melaksanakan proses pengadaan itu sendiri [4].

Saat ini proses pengadaan di berbagai organisasi telah melibatkan sistem informasi sebagai pendukung dan penyimpan data historis. Sistem Informasi telah menjadi alat integral, online dan interaktif yang terlibat mendalam pada operasi menit per menit dan pengambilan keputusan organisasi-organisasi besar. Selama dekade terakhir, sistem informasi telah mengubah organisasi-organisasi ekonomi secara fundamental dan sangat banyak meningkatkan kemungkinan untuk mengatur pekerjaan [5].

Suatu Sistem Informasi (SI) mengumpulkan, memproses, menyimpan, menganalisis dan mendistribusikan informasi untuk suatu tujuan tertentu [12]. Peningkatan biaya operasional yang tidak diiringi dengan peningkatan jumlah pasien menekan rumah sakit untuk mencari sumber permasalahan pembengkakan biaya operasional. Biaya logistik untuk kebutuhan perawatan pasien yang tidak berkurang meski terjadi penurunan BOR (Bed Occupancy Rate) maupun biaya logistik bahan medis dan non medis ruang perawatan yang terus meningkat tanpa adanya peningkatan revenue dari tagihan rawat inap menggerakkan manajemen untuk membatasi pengeluaran bahan kebutuhan ruang rawat inap. Akibatnya, banyak keluhan dari perawat dan pasien mengenai keperawatan.

Mengacu kepada permasalahan yang dihadapi manajemen, peneliti melakukan observasi dan wawancara kepada perawat, karyawan logistik dan petugas administrasi rawat inap. Dari sumber-sumber tersebut, peneliti menemukan beberapa permasalahan yang perlu diteliti lebih lanjut; salah satunya adalah penagihan bahan habis pakai ruangan rawat inap.

Alur distribusi bahan habis pakai dari logistik hingga penagihan kepada pasien dapat dilihat pada Gambar 2.

\section{Metodologi}

James Wetherbe memperkenalkan suatu kerangka kerja yang berguna untuk klasifikasi masalah, kesempatan dan arah perubahan dalam sistem informasi yang disebutnya PIECES (Performance Information Economics Control Efficiency Service) [14].

Peneliti menggunakan kerangka kerja PIECES untuk mengevaluasi penggunaan sistem billing pasien rawat inap, terutama untuk penagihan bahan habis pakai. Melalui analisis tersebut, diharapkan dapat menjawab kebutuhan manajemen guna mendayagunakan sistem informasi yang ada untuk merencanakan logistik bahan ruangan perawatan.

Dalam penelitian ini, akan digunakan kuesioner, pengamatan dan wawancara untuk mengumpulkan data primer. Sedangkan data sekunder didapat dari berbagai buku, jurnal, dan penelitian yang pernah dilakukan terkait dengan sistem billing rumah sakit, manajemen logistik maupun procurement di rumah sakit.
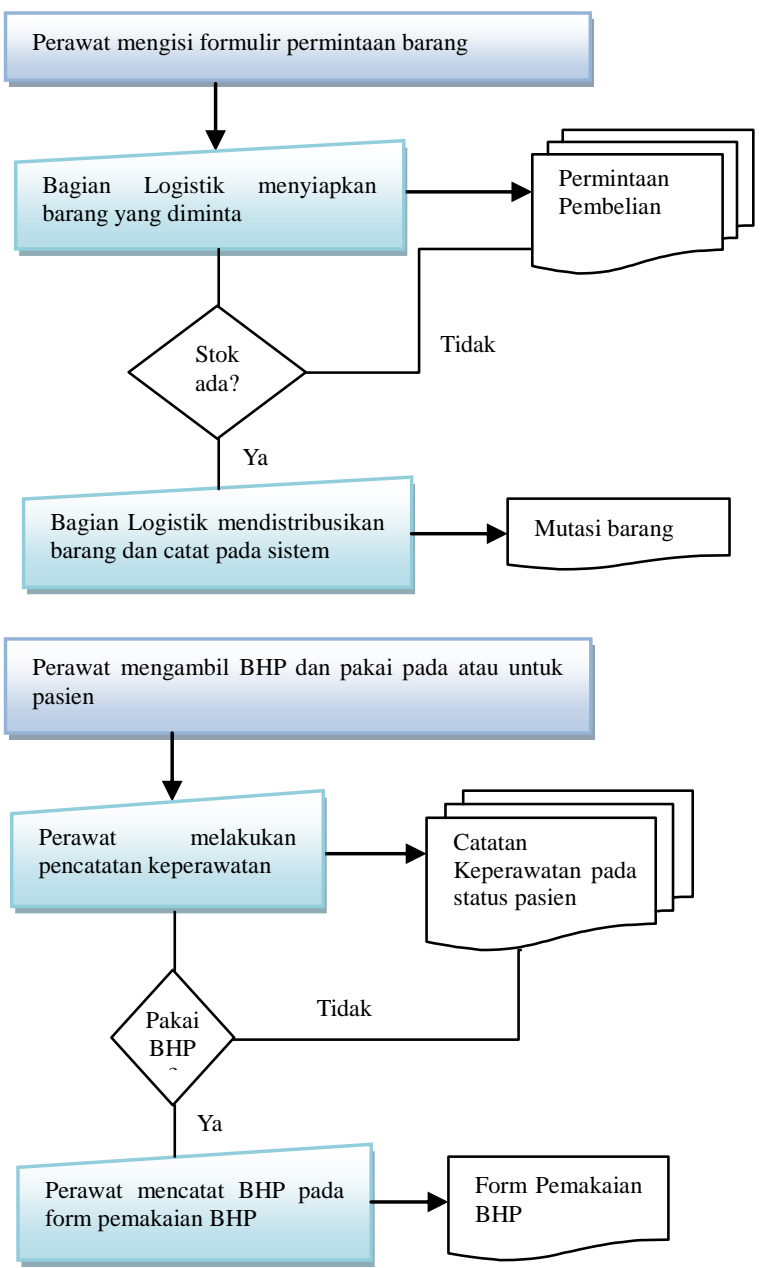

Gambar 2. Alur distribusi bahan habis pakai

Kuesioner memuat 6 (enam) variabel yang masing-masing mewakili keenam subjek dalam pendekatan PIECES. Masing-masing variabel memiliki indikator untuk mendapatkan data mengenai kinerja, informasi, biaya, kontrol, efisiensi dan layanan dari sistem billing pasien rawat inap. Jawaban dari setiap pertanyaan memiliki bobot sendiri untuk diinterpretasikan kemudian.

Metode sampling menggunakan one shot sampling yaitu seluruh populasi digunakan 
sebagai responden. Kuesioner akan diberikan kepada para pengguna sistem billing rawat inap yang hendak dikaji, yaitu petugas administrasi ruang rawat inap sebagai pengguna utama dan kasir sebagai pengguna kedua. Seluruh petugas administrasi ruang rawat inap dan kasir yang sudah bekerja lebih dari 2 (dua) tahun akan menjadi responden penelitian ini.

Petugas administrasi ruangan adalah petugas yang memiliki tanggung jawab untuk membuat tagihan kepada pasien, sedangkan kasir hanya menerima pembayaran dari pasien. Kasir-kasir yang sudah bekerja lebih dari 2 (dua) tahun mempunyai pengalaman yang lebih banyak dengan tagihan rawat inap pasien sehingga cukup mengerti dengan sistem penagihan, oleh karena itu layak diikutkan sebagai responden kuesioner.

\section{Hasil dan Analisis}

Dari hasil pengumpulan data melalui kuesioner, peneliti mendapatkan data yang dipetakan dalam kerangka PIECES sebagai berikut:

TABEL I

PEMETAAN HASIL KUESIONER

\begin{tabular}{|c|c|c|c|c|c|}
\hline Variabel & Selalu & Sering & $\begin{array}{c}\text { Kadang- } \\
\text { Kadang }\end{array}$ & Sesekali & $\begin{array}{r}\text { Tidak } \\
\text { Pernah }\end{array}$ \\
\hline Performance & $42,5 \%$ & $42,5 \%$ & $10,0 \%$ & $5,0 \%$ & $0,0 \%$ \\
\hline Information & $66,7 \%$ & $15,0 \%$ & $5,0 \%$ & $1,7 \%$ & $11,7 \%$ \\
\hline Economics & $40,0 \%$ & $32,5 \%$ & $17,5 \%$ & $7,5 \%$ & $2,5 \%$ \\
\hline Control & $30,0 \%$ & $12,5 \%$ & $10,0 \%$ & $30,0 \%$ & $17,5 \%$ \\
\hline Efficiency & $53,3 \%$ & $28,3 \%$ & $13,3 \%$ & $5,0 \%$ & $0,0 \%$ \\
\hline Service & $50,0 \%$ & $40,0 \%$ & $10,0 \%$ & $0,0 \%$ & $0,0 \%$ \\
\hline
\end{tabular}

Dari Tabel 1, dapat digambarkan grafik batang yang menggambarkan prosentase jawaban pengguna untuk setiap variabel PIECES yang dapat dilihat pada Gambar 3.

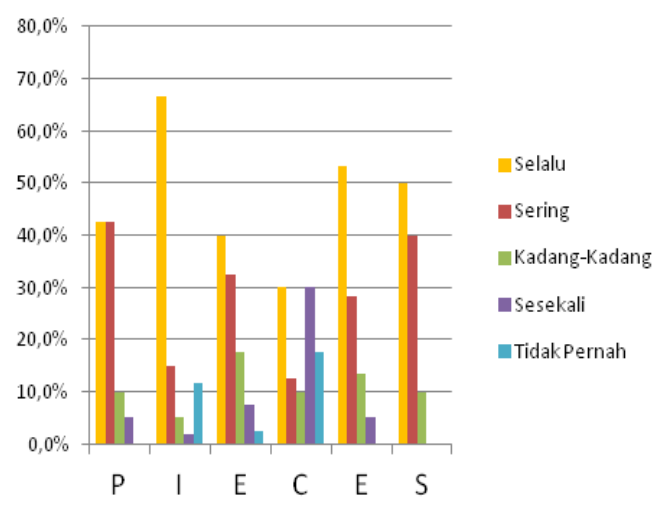

Gambar 3. Grafik hasil kuesioner
Berdasarkan data dari kuesioner, analisis PIECES terhadap sistem billing pasien rawat inap dapat diuraikan sebagai berikut:

Performance sistem billing pasien rawat inap menurut penggunanya sudah baik, hanya kecepatan pencetakan tagihan pasien rawat inap masih belum memuaskan. Sedangkan kecepatan mencetak sangat tergantung pada kecepatan printer. Saat ini pencetakan tagihan masih menggunakan printer dot matrix karena kebutuhan pencetakan beberapa rangkap. Kinerja dalam pencetakan perincian tagihan rawat inap perlu ditingkatkan untuk mempercepat pelayanan kepada pasien. Secara keseluruhan, pengguna cukup puas dengan kinerja sistem billing pasien rawat inap.

\section{Kepuasan Pengguna Terhadap Kinerja Sistem}

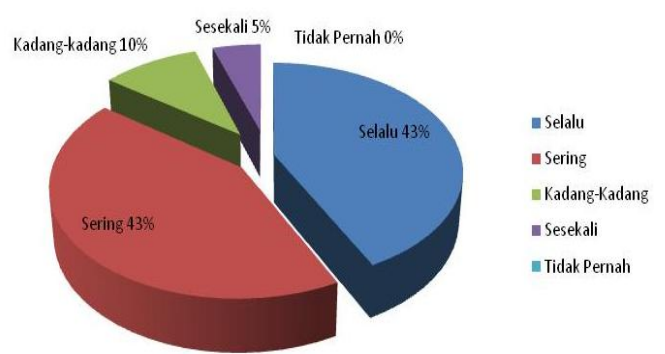

\section{Gambar 4. Grafik kinerja sistem billing}

Sistem billing dapat menghasilkan laporanlaporan (informasi) yang mendukung operasional rumah sakit, namun sayangnya laporan-laporan tersebut masih kurang memadai untuk kebutuhan manajemen, terutama manajemen logisik dalam hal ini laporan BHP. Ketersediaan laporan BHP yang dimaksudkan oleh pengguna ternyata adalah laporan perincian tagihan pasien sehingga untuk menghitung pemakaian BHP pada setiap ruang perawatan masih sulit. Walaupun demikian, data yang diperlukan sistem billing dapat terpenuhi dengan baik dan informasi yang diperlukan selalu tersedia dengan frekuensi melebihi $50 \%$ (lima puluh persen).

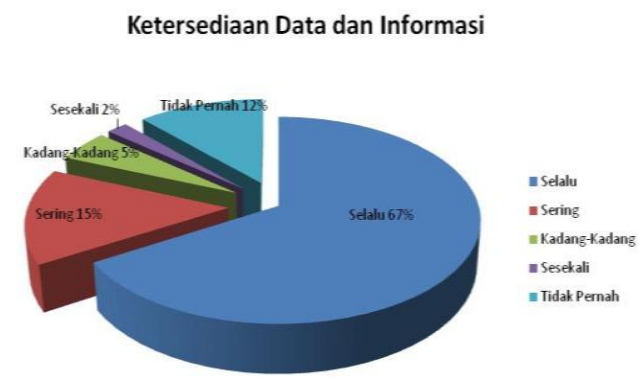

Gambar 5. Grafik ketersediaan informasi sistem billing 
Sistem billing memang memerlukan sumber daya yang lebih besar, namun sistem billing memberikan keuntungan yang lebih besar dengan mempercepat proses penagihan dan memberikan hasil kalkulasi yang lebih akurat sehingga pasien dapat dilayani dengan lebih cepat dan baik. Pengguna sistem billing banyak merasakan keuntungan penggunaan sistem billing pasien rawat inap dengan persentase hingga $73 \%$ (tujuh puluh tiga persen).

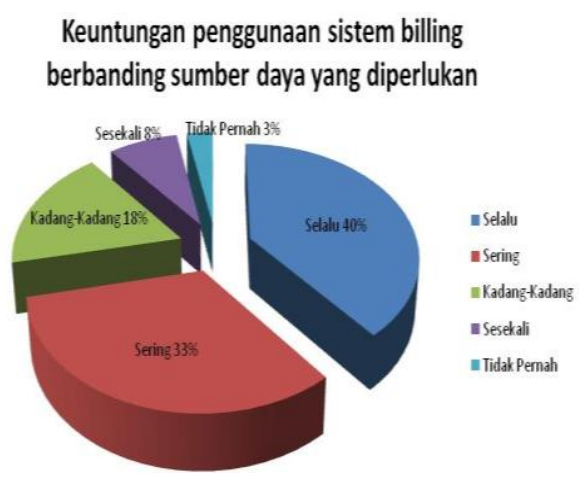

Gambar 6. Grafik nilai ekonomis sistem billing

Kontrol terhadap pengguna sistem masih sangat minim sehingga sering terjadi kesalahan manusia pada sistem billing rawat inap, terutama untuk pencatatan dan penagihan bahan habis pakai. Kesalahan pengguna yang kemudian menyebabkan kesalahan sistem perlu diminimalkan dengan training dan pelatihan penggunaan sistem billing pasien rawat inap bagi pengguna-penggunanya.

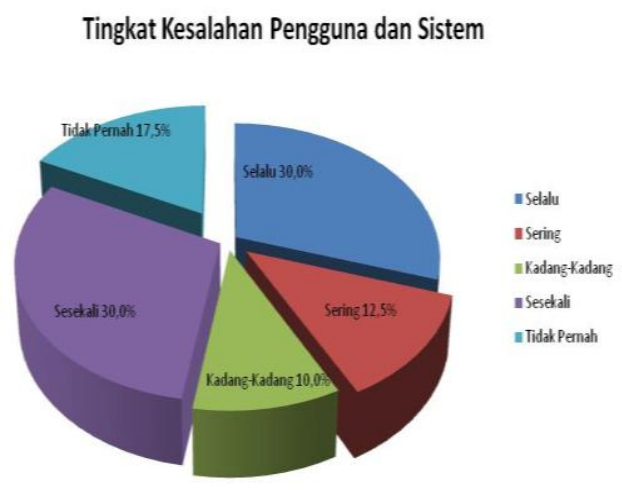

Gambar 7. Grafik tingkat kontrol sistem billing

Efficiency; Penggunaan sistem billing rawat inap untuk penagihan bahan habis pakai belum $100 \%$ efisien karena masih banyak human error yang terjadi pada saat pencatatan dan input ke sistem billing. Perancangan layar pada sistem billing juga masih membingungkan bagi pengguna baru. Bagi pengguna, sistem billing berguna untuk mempercepat penagihan pasien rawat inap, dalam hal ini penagihan bahan habis pakai. Namun, pengguna juga menyebutkan bahwa tidak semua bahan habis pakai tertagih melalui sistem billing. Hal ini mencermin daya guna sistem yang masih patut dipertanyakan.

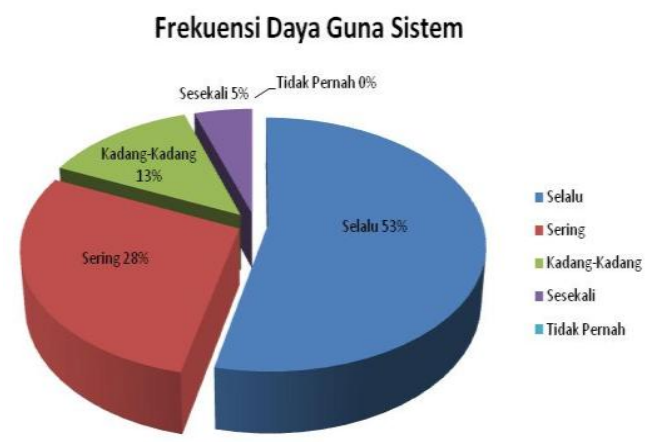

Gambar 8. Grafik efisiensi sistem billing

Service; Sistem billing belum sepenuhnya kompatibel dengan sistem logistik, terutama untuk bahan habis pakai. Masih ada bahan-bahan habis pakai yang tidak terdapat pada sistem billing, walaupun sudah didistribusikan dari logistik ke ruangan perawatan. Sosialisasi bahan medis dan non medis baru juga masih minim sehingga pengguna kadang tidak mengetahui adanya bahan habis pakai yang baru.

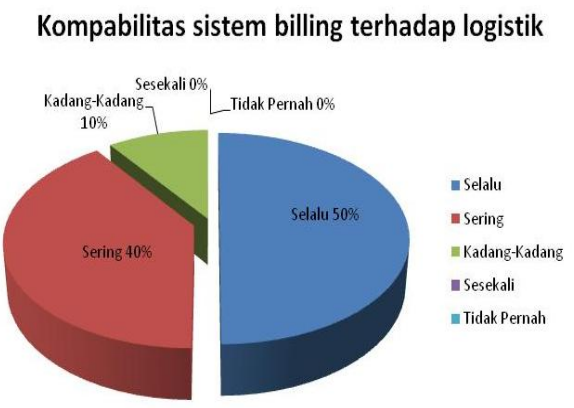

Gambar 9. Grafik kompabilitas sistem billing terhadap SIM logistik

\section{Kesimpulan}

Dari data yang dikumpulkan, peneliti menarik kesimpulan dari beberapa temuan. Penggunaan sistem billing pasien rawat inap untuk penagihan bahan habis pakai di Rumah Sakit ProMedika saat ini sudah cukup baik secara kinerja. Data yang dijadikan input bagi sistem billing terutama untuk penagihan bahan habis pakai sudah baik, namun kontrol terhadap pengguna dan validitas data tersebut masih kurang karena semua tindakan dan bahan habis pakai yang digunakan perawat juga dicatat oleh perawat yang sama. Laporan-laporan dari sistem billing pasien rawat inap saat ini sudah mendukung untuk 
keputusan operasional. Secara bisnis, sistem billing meningkatkan kecepatan pelayanan kepada pasien rawat inap yang akan pulang karena dapat segera menyelesaikan tagihannya. Akibat kurangnya kontrol, tentunya efisiensi sistem billing juga tidak maksimal sehingga kontribusi yang seharusnya dapat diberikan oleh sistem billing bagi komponen manajerial lainnya tidak diperhatikan.

Laporan bahan habis pakai yang ada seharusnya dapat digunakan untuk manajemen logistik. Namun, laporan-laporan tersebut belum dirancang untuk kebutuhan logistik sehingga memerlukan usaha yang lebih banyak untuk mencari tahu ruangan tempat pasien dirawat supaya dapat diketahui bahan habis pakai yang ditagih berasal dari ruangan mana. Kerancuan dapat terjadi ketika ada pasien yang pindah ruangan selama dirawat. Maka perlu ada pengembangan sistem pelaporan dari tagihan bahan habis pakai pasien rawat inap.

\section{Referensi}

[1] DeJohn, Paula. "Managing Logistics Costs Pays off in Lowering Overall Supply Expense." The Newsletter for Hospital Material Management and Group Purchasing vol.31 May 2005. Hcpro.com, Web. Mar.Apr. 2012.

[2] Dwiantara, Lukas, dan Rumsari Hadi Sumarto. Manajemen Logistik Pedoman Praktis Bagi Sekretaris dan Staf Administrasi, Grasindo, Jakarta 2004.

[3] Hidayat, Mohammad Kuntadi Syamsul, Hari Kusnanto, and Adi Utarini. "Pengembangan Sistem Tagihan Dengan Model Diagnosis Related Group Di Rumah Sakit Dr. Syaiful Anwar Malang." Jurnal Manajemen Pelayanan Kesehatan 3.3 (2000): 145-49. Web.

[4] Komatas, Theodoros A. "The Role of Medical and Nursing Staff in the Procurement Process: The Case of State Hospitals in Greece." European Journal of Social Solidarity 26.3 (2011): 335-30. European Journal of Social Siences. EuroJournals Publishing, Inc 2011. Web. Mar.-Apr. 2012. $<$ http://www.europeanjournalofsocialscience s.com>.

[5] Laudon, Kenneth C., and Jane Price.
Laudon. Essentials of Management Information Systems. Boston: Prentice Hall, 2011.

[6] Mettler, Tobias, and Peter Rohner. "EProcurement in Hospital Pharmacies: An Exploratory Multi-Case Study from Switzerland." Journal of Theoretical and Applied Electronic Commerce Research 4.1 (2009): 23-38. JTAER.com. Web. Mar.-Apr. 2012. <www.jtaer.com>.

[7] Mitchell, Colby L., Ernest R. Anderson,Jr, and LeeAnn Braun. "Billing for Inpatient Hospital Care." American Society of HealthSystem Pharmacists 60 (2003): S8-S11. American Society of Health System Pharmacists, Nov. 2003. Web. Feb.-Mar. 2012. 〈www.seekpdf.net>.

[8] O'Brien, James A., and George M. Marakas. Management Information Systems. New York: McGraw-Hill/Irwin, 2011.

[9] Rainer, R. Kelly, and Casey G. Cegielski. Introduction to Information Systems: Supporting and Transforming Business. Hoboken, NJ: Wiley, 2012.

[10] Rothmeier, Jeffrey. "Choosing a Medical Billing System." American Federation of Information Processing Societies (1977): 965-68. National Computer Conference, 1977. Web. Feb.-Mar. 2012. <www.computerhistory.org>.

[11] Turban, Efraim, Ephraim R. McLean, James C. Wetherbe, and D. E. Leidner. Information Technology for Management: Transforming Organizations in the Digital Economy. Hoboken: Wiley, 2004.

[12] Turban, Efraim, Linda Volonino, and Janice C. Sipior. Information Technology for Management. Hoboken, N.J: Wiley, 2011.

[13] Undang-Undang Republik Indonesia No.44 tahun 2009 tentang Rumah Sakit

[14] Whitten, Jeffrey L., and Lonnie D. Bentley. Introduction to Systems Analysis \& Design. Boston, Mass. u.a.: McGraw-Hill/Irwin, 2008.

[15] http://www.businessdictionary.com/definitio n/procurement.html, diakses maret 2012.

[16] http://www.hayajneh.org/glossary/vocabular $\mathrm{y} / \mathrm{h} /$ HospitalInformationSystemHIS.html, diakses tanggal 28 April 2012

[17] http://www.medterms.com/script/main/art.as $\mathrm{p}$ ?articlekey $=8390$, diakses tanggal 28 April 2012 